\title{
Pedoman Resusitasi Syok Septik “Surviving Sepsis Campaign” Butuh Penyesuaian
}

\author{
Antonius H. Pudjiadi \\ Departemen Ilmu Kesehatan Anak Fakultas Kedokteran Universitas Indonesia/RSUPN Dr. Cipto Mangunkusumo, Jakarta \\ Surviving sepsis campaign (SSC) mengeluarkan pedoman tata laksana klinis pasien sepsis. Pedoman tata laksana ini dibuat atas dasar \\ ilmu kedokteran berbasis bukti berdasarkan data pasien sepsis dewasa. Dalam panduannya, terdapat target-target tata laksana yang \\ perlu dicapai dalam batas waktu tertentu, termasuk target hemodinamik sebagai panduan resusitasi, seperti jumlah cairan resusitasi, \\ rerata tekanan arteri, dan tekanan vena sentral. Makalah ini bertujuan untuk mengupas permasalahan dari adaptasi target SSC, \\ khususnya pada pasien anak di Indonesia. Sari Pediatri 2020;21(5):329-32
}

Kata kunci: surviving sepsis campaign, cairan resusitasi, target hemodinamik

\section{Surviving Sepsis Campaign Guidelines for Septic Shock Resuscitation Need an Adaptation}

Antonius H. Pudjiadi

Surviving sepsis campaign (SSC) issued guidelines for the clinical management of patients with sepsis. These guidelines were based on evidence-based medicine based on data of adult sepsis patient. In this bundle, there are targets that need to be achieved within a certain time limit, including hemodynamic targets as a guide for resuscitation, such as the amount of resuscitation fluid, mean arterial pressure, and central venous pressure. This paper aims to explore the problem of adaptation of SSC targets, especially in pediatric patients in Indonesia. Sari Pediatri 2020;21(5):329-32

Keyword: surviving sepsis campaign, fluid resuscitation, hemodynamic target

Alamat korespondensi: Antonius H. Pudjiadi. Departemen Ilmu Kesehatan Anak Fakultas Kedokteran Universitas Indonesia. RSUPN Dr Cipto Mangunkusumo. Jl. Salemba Raya No. 6, Jakarta 10430. Email: ahpudjiadi@gmail.com 


\section{Sejarah}

Surviving sepsis campaign (SSC) adalah langkah-langkah yang disusun dengan tujuan untuk menurunkan mortalitas sepsis. Kesepakatan ini pertama kali dicetuskan pada tahun 2002, atas inisiatif para ahli yang tergabung dalam perhimpunan Society of Critical Care Medicine (SCCM), European Society of Intensive Care Medicine (ESICM) dan International Sepsis Forum (ISF). Salah satu produk SSC adalah panduan tata laksana klinis (guidelines) yang disusun mengikuti kaidah kedokteran berbasis bukti (evidence-based medicine), pertama kali diterbitkan pada tahun 2004.", ${ }^{2}$ Panduan pertama ini tidak dirancang untuk populasi anak sehingga dibutuhkan banyak penyesuaian. Sekalipun penelitian pada anak tidak sebanyak dewasa, definisi sepsis dan disfungsi organ pediatrik disepakati pada konsensus internasional pada tahun 2005. ${ }^{3}$ Pembaharuan panduan tata laksana klinis SSC, sesuai penelitian terbaru, diterbitkan pada tahun 2008 dan 2012, yang memuat rekomendasi tersendiri untuk populasi pediatrik. ${ }^{4-7}$

\section{Penerapan}

Karena publikasi dari negara berkembang terbatas, sebagian besar publikasi yang digunakan dalam penyusunan panduan tersebut berasal dari negara maju. Panduan tersebut dibuat menggunakan parameter hemodinamik yang diukur dengan peralatan invasif. Seiring dengan perkembangan teknologi kedokteran, saat ini tersedia peralatan yang lebih murah dan dapat digunakan secara bedside untuk mengukur parameter hemodinamik pasien dengan akurasi yang cukup baik. Teknologi digital juga menghasilkan banyak parameter baru yang akhirnya mengubah praktek tata laksana hemodinamik menjadi lebih individual. Publikasi dari negara berkembang yang semakin banyak memperlihatkan terdapatnya perbedaan populasi sepsis, baik dari segi penyebab infeksi maupun dari segi penjamu. Karena menganggap definisi sepsis yang dianut dalam panduan klinis SSC internasional tidak memadai, Ikatan Dokter Anak Indonesia mulai menyusun definisi sepsis pediatrik yang baru pada tahun 2012. Pada tahun 2016 terbit juga konsensus internasional tentang definisi sepsis dan syok septik baru yang lebih ditujukan untuk populasi dewasa.
Namun demikian, secara konsep definisi ini sama dengan pemikiran sejawat di Ikatan Dokter Anak Indonesia, sepsis adalah kondisi gagal organ multipel yang disebabkan respon imun yang salah terhadap infeksi. ${ }^{8}$ Konsekuensi dari batasan baru ini adalah perbedaan fenotip pasien sepsis akibat berbagai keadaan yang terjadi secara kebetulan, antara lain, dipengaruhi usia, komorbid, sumber infeksi, penyebab infeksi, dan tata laksana. ${ }^{9}$ Meskipun demikian, di antara sekian banyak kemungkinan yang dapat terjaditerdapat beberapa kesamaan, yaitu (1) Mikroorganisme 'asing' penyebab infeksi harus dapat disingkirkan oleh penjamu dalam waktu singkat. (2) Kegagalan dan keterlambatan resusitasi meningkatkan mortalitas dan atau kecacatan. Karena itu, di negara dengan tingkat mortalitas yang sangat tinggi, panduan tata laksana apapun yang menyebabkan penghilangan sumber infeksi, penggunaan antibiotik yang tepat dengan lebih cepat, dan teknik resusitasi yang lebih baik akan menurunkan angka kematian. Untuk menurunkan mortalitas sepsis di negara dengan mortalitas yang sudah sangat rendah diperlukan tata laksana sepsis sesuai fenotip respon imun pasien.

\section{Target Hemodinamik}

Untuk memudahkan tata laksana di lapangan, panduan klinis SSC mengeluarkan target yang harus dicapai dalam ukuran waktu, dikenal dengan SSC bundles. Bundle yang paling kontroversial pada panduan klinis SSC 2012 adalah (1) pemberian cairan kristaloid 30 $\mathrm{mL} / \mathrm{kg}$ untuk pasien dengan hipotensi atau pasien dengan kadar laktat $\geq 4 \mathrm{mmol} / \mathrm{L}$ yang harus sudah selesai pada jam ke-3, (2) target mean arterial pressure (MAP) $\geq 65 \mathrm{mmHg}$ (dewasa) yang harus dicapai dalam 1 jam, dan (3) target central venous pressure (CVP) $\geq 8 \mathrm{mmHg}$ yang juga harus dicapai dalam 6 jam. Kelemahan bundle ini adalah tidak memperhatikan fenotip pasien. Penelitian kami, di RSUPN Dr Cipto Mangunkusumo, membuktikan bahwa cairan resusitasi untuk anak sepsis mengakibatkan hemodilusi hingga tidak meningkatkan pasokan oksigen tubuh $\left(\mathrm{DO}_{2}\right) .{ }^{10}$ Penelitian Maitland $\mathrm{dkk}^{11}$ memperlihatkan bahwa pemberian cairan resusitasi secara cepat (bolus) meningkatkan kematian anak dengan infeksi di Africa. Penargetan MAP tanpa melihat fenotip pasien juga berpotensi mengakibatkan komplikasi. Penelitian kami, pada hewan coba di Fakultas Kedokteran Hewan Institut Pertanian 
Bogor, memperlihatkan bahwa penurunan systemic vascular resistance (SVR) merupakan proteksi untuk mengurangi beban jantung, sekaligus membatasi extravascular lung water. ${ }^{12}$ Target utama pada resusitasi adalah memperbaiki perfusi. Perbaikan perfusi dapat dicapai dengan meningkatkan MAP atau menurunkan tekanan di area target perfusi. Misalnya, perbaikan cerebral perfusion pressure pada meningitis dapat dicapai dengan menurunkan tekanan intrakranial, abdominal perfusion pressure dapat diperbaiki dengan menurunkan tekanan intraabdominal pada sindroma kompartemen abdomen. Meningkatkan CVP, seperti ditargetkan pada SSC bundle 2012, berpotensi menurunkan perfusi secara keseluruhan. Di samping itu, CVP yang tinggi pada dasarnya terjadi akibat penurunan komplians vena sentral. CVP yang tinggi juga terjadi pada gagal jantung.

Pada tahun 2017, The American College of Critical Care Medicine memperbaharui panduan praktis tunjangan hemodinamik anak dan neonatus dengan syok septik. ${ }^{13}$ Pada panduan baru ini, tata laksana hemodinamik dilakukan dengan lebih berhati-hati dengan menggunakan berbagai modalitas terapi. Target resusitasi pada pendoman ini: waktu pengisian kapiler $<3$ detik, MAP-CVP sesuai usia, cardiac index (CI) 3,3-6,0 L/menit $/ \mathrm{m}^{2}$, systemic vascular resistance index (SVRI) 800-1200 dyne sec/m², $\mathrm{ScVO}_{2}>70 \%$, dan balans cairan 0. Penelitian kami, di RSUPN Dr Cipto Mangunkusumo, memperlihatkan bahwa setelah target tersebut dicapai, masih terdapat perbedaan fenotip pasien sehingga membutuhkan tata laksana lebih lanjut yang berbeda-beda. ${ }^{14}$ Hambatan lain di Indonesia adalah sistem rujukan yang belum baku hingga target waktu yang dianjurkan panduan SSC sulit dipenuhi, bahkan merubah fenotip pasien.

\section{Kesimpulan}

Panduan tata laksana klinis SSC dapat menurunkan mortalitas sepsis anak di negara dengan mortalitas sepsis masih tinggi. Penggunaannya di negara berkembang membutuhkan adaptasi sesuai populasi pasien, epidemiologi, fasilitas pelayanan kesehatan dan sistem pelayanan kesehatan, termasuk sistem rujukan. Peralatan kesehatan modern memungkinkan penilaian pasien secara individual dengan biaya yang lebih murah. Dengan teknologi baru ini, target yang ditetapkan panduan tata laksana klinis SSC perlu disikapi secara dinamis. Penilaian secara individual memungkinkan tata laksana yang lebih tepat sesuai fenotip pasien.

\section{Daftar pustaka}

1. Dellinger RP, Carlet JM, Masur H, dkk. Surviving sepsis campaign guidelines for management of severe sepsis and septic shock. Intensive Care Med 2004;30:536-55.

2. Dellinger RP, Carlet JM, Masur H, dkk. Surviving sepsis campaign guidelines for management of severe sepsis and septic shock. Crit Care Med 2004;32:858-73.

3. Goldstein B, Giroir B, Randolph A, dan International Consensus Conference on Pediatric S. International pediatric sepsis consensus conference: definitions for sepsis and organ dysfunction in pediatrics. Pediatr Crit Care Med 2005;6:2-8.

4. Dellinger RP, Levy MM, Carlet JM, dkk. Surviving sepsis campaign: international guidelines for management of severe sepsis and septic shock: 2008. Crit Care Med 2008;36:296327.

5. Dellinger RP, Levy MM, Carlet JM, dkk. Surviving sepsis campaign: international guidelines for management of severe sepsis and septic shock: 2008. Intensive Care Med 2008;34:1760.

6. Dellinger RP, Levy MM, Rhodes A, dkk. Surviving sepsis campaign: international guidelines for management of severe sepsis and septic shock, 2012. Intensive Care Med 2013;39: 165-228.

7. Dellinger RP, Levy MM, Rhodes A, dkk. Surviving sepsis campaign: international guidelines for management of severe sepsis and septic shock: 2012. Crit Care Med 2013;41:580637.

8. Singer M, Deutschman CS, Seymour CW, dkk. The third international consensus definitions for sepsis and septic shock (sepsis-3). JAMA 2016;315:801-10.

9. Leligdowicz A and Matthay MA. Heterogeneity in sepsis: new biological evidence with clinical applications. Crit Care 2019;23:80.

10. Saputra I, Pudjiadi AH and Yuniar I. Perubahan indeks curah jantung dan pasokan oksigen pada anak renjatan sepsis pascabolus cairan. 2019 (submitted).

11. Maitland K, Kiguli S, Opoka RO, dkk. Mortality after fluid bolus in African children with severe infection. N Engl J Med 2011;364:2483-95.

12. Pudjiadi AH, Firmansyah A, Gunanti, dkk. The impact of fluid resuscitation on hemodynamic of hemorrhagic shhock: an animal model experimental study. 2019 (submitted).

13. Davis AL, Carcillo JA, Aneja RK, dkk. The American College 
Antonius H. Pudjiadi: Pedoman resusitasi syok septik "surviving sepsis campaign" butuh penyesuaian

of Critical Care Medicine Clinical Practice Parameters for Hemodynamic Support of Pediatric and Neonatal Septic Shock: Executive Summary. Pediatr Crit Care Med 2017;18:884-90.
14. Yuliarto S, Pudjiadi AH, dan Latief A. Hemodynamic alterations in pediatrics shock after fluid resuscitation and vasoactive drugs administration: a prospective observational study. 2019 (submitted). 